\title{
BIOSTRATIGRAPHY (CALCAREOUS NANNOFOSSILS AND MOLLUSCS) OF THE PANNONIAN DEPOSITS FROM TRANSYLVANIA, ROMANIA (GUŞTERIŢA QUARRY - SIBIU)
}

\author{
Carmen Mariana Chira ${ }^{1 *}$, Carlo Aroldi ${ }^{1}$, Mirela Violetta Popa ${ }^{1}$, Sergiu-Nicolae Şerban ${ }^{1}$, \\ Traian-Ioachim Suciu' ${ }^{1} \&$ Raluca Bindiu-Haitonic ${ }^{1}$
}

Received: 17 December 2020 / Accepted: 10 April 2021 / Published online: 17 April 2021

\begin{abstract}
Three sections from the upper Miocene (Pannonian) of the Guşteriţa quarry - Sibiu (the southern border of the Transylvanian Basin) were investigated in detail. The main part of the research was based on calcareous nannofossil analysis to which some aspects on molluscs and ostracods fauna, together with sedimentological remarks were added. The calcareous nannofossil assemblages from Guşteriţa quarry were compared with seven other previously analyzed sections from the western border of the Transylvanian Basin: Aiud area (Geoagiu, Gârbova, Gârbovița, Lopadea exposures and Decea quarry) and Sibiu area (Vurpăr and Apoldu exposures).

The Pannonian calcareous nannofossil assemblages are abundant at some levels and contain mostly species of the genera Isolithus and Noelaerhabdus.
\end{abstract}

Keywords: Guşteriţa Formation, Upper Miocene, calcareous nannofossils, ostracods, molluscs, sedimentology.

\section{INTRODUCTION}

The study is focused especially on the Pannonian (Upper Miocene) calcareous nannofossils from Guşteriţa quarry, near Sibiu.

Three sections belonging to Guşteriţa Formation from the Guşteriţa quarry have been investigated in order to identify the Pannonian calcareous nannofossils from the southern Transylvanian Basin area (Romania). They were compared with seven other previously investigated areas, from the western border of the Transylvanian Basin, in the Aiud area, between Turda and Alba Iulia, respectively Geoagiu, Gârbova, Gârboviţa and Lopadea exposures together with Decea quarry. In the Sibiu area, Vurpăr and Apoldu exposures have been previously investigated (Chira \& Malacu, 2008).

The Guşteriţa Formation was described from the southern border of the Transylvanian Basin (Lubenescu, 1981) in the Sibiu - Guşteriţa (Hermannstadt - Hammersdorf) area (Fig. 1). This formation is represented by a pelitic facies with Congeria banatica; in particular, in the area of the localities Apold, Gârbova, Dobârca, Guşteriţa and Alămor (respectively from west to east of Sibiu), it is characterized by the predominance of poorly compacted mudstones with minor intercalations of siltstones. These facies were observed along Rodului Valley, between Apoldu de Sus and Apoldu de Jos. In the uppermost part these beds are represented especially by poorly cemented sandstones (Lubenescu, 1981).

\section{GEOLOGICAL SETTING}

The Transylvanian Basin is considered a passive sag basin with middle-upper Miocene sediments that reached up to $3.5 \mathrm{~km}$ in its center (Krézsek \& Bally, 2006). The only detectable extensional deformation consists of early Badenian normal faults showing offsets up to a couple of hundred meters, which can only partially explain the observed entire Badenian-Pannonian Basin subsidence. This sag subsidence postdates the early Miocene - early Sarmatian phase of extension observed in the Pannonian Basin. In the Transylvanian Basin, the BadenianSarmatian sag deposition was followed by a general subsidence and then by a gradual regressive episode of basin fill during Pannonian (Krézsek et al., 2010). This last phase was interrupted by the exhumation of the Transylvanian Basin toward the end of Pannonian stage due to the collision that took place in the outer Carpathians. The coupling between the mechanical extension of the Pannonian Basin and its thermal effects recorded in the Transylvanian Basin should have taken place in such a way that the intervening Apuseni Mountains did not suffer any significant Miocene vertical movements.

A sequence stratigraphic framework for the Pannonian in the Transylvanian Basin was proposed by Krézsek \& Filipescu (2005) and Krézsek et al. (2010). They divided the middle to late Miocene sedimentary succession of the basin into minimum eight different sequences based on seismic profiles and well logs. The Pannonian sediments included the following system tracts: TST7, HST7, LST8, TST8, HST8 and LST9 (Krézsek \& Filipescu, 2005; Krézsek et al., 2010).

${ }^{1}$ Babeș-Bolyai University, Department of Geology and Center for Integrated Geological Studies, 1 Kogălniceanu Street, RO 400084, Cluj-Napoca, Romania, carmen.chira@ubbcluj.ro; carlo.aroldi@ubbcluj.ro; mirela.popa@ubbcluj.ro; sergiu.serban@ymail.com; suciutraian26@yahoo.com; raluca.haitonic@ubbcluj.ro

* Corresponding author 


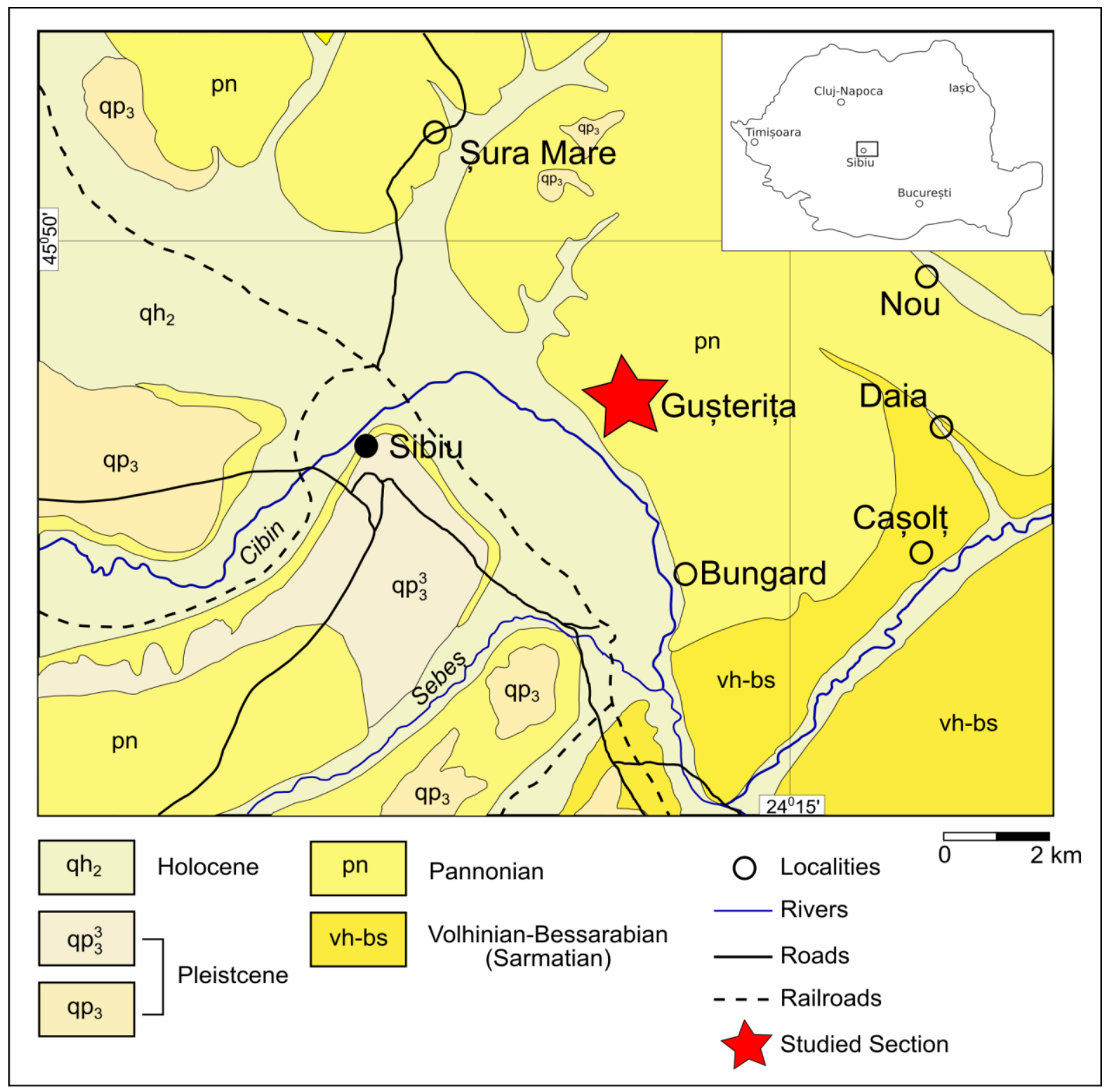

Fig. 1 Simplified geological map 1:200.000 after Dessila Codarcea et al., 1968.

The Pannonian sediments from the western part of the Transylvanian Basin belong to the Lopadea Formation. Lithologically, they are represented mostly by sandstones with various degrees of cementation, mudstones and conglomerates (Lubenescu \& Lubenescu, 1977).

The Pannonian deposits from Sibiu area belong to the Guşteriţa Formation and are represented by a pelitic facies with Congeria banatica (Lubenescu, 1981).

The Pannonian macrofauna of Guşteriţa was investigated by Ackner, 1852; Lörenthey, 1893; Bielz, 1894; Lubenescu, 1981; Botka et al., 2019, and others.

In the assemblages with Congeria banatica (around the localities Apoldu de Sus, Dobârca, Guşteriţa, Turnişor, Boz and Dostat) Congeria digitifera, Paradacna lenzi, $P$. syrmiensis, Acicardium costatum, A. protractum, Velutinopsis velutina, Undulotheca pancici, $U$. rotundata were also identified. Congeria banatica, Undulotheca pancici, U. rotundata, prove the Middle to Late Pannonian age (Lubenescu, 1981).
Other species founding in the Gușterița area are: Gyraulus ponticus, Gyraulus praeponticus, Orygoceras fuchsi brusinai, Undulotheca nobilis, Undulotheca rotundata, Pectinaria ostracopannonicus (trace fossil), Diplocraterion sp. (trace fossil), Silicoplacentina majzoni (thecamoebian), Pectinaria gigantea, Gadidae (fish teeth) and otoliths (Botka et al. 2018; 2019). Palynological studies were realized by Baranyi et al. $(2019 ; 2021)$.

\section{MATERIAL AND METHODS}

15 samples were collected from three sections of the Guşteriţa quarry, between 2017 and 2019, during field trips with the students of the Babeş-Bolyai University. The samples were investigated for calcareous nannofossils content. The smear slides for calcareous nannofossils were prepared using the standard smear slide technique (Bown \&Young, 1998) and were studied under an optical microscope, at $1000 \mathrm{X}$ magnification. Analyses were con- 
ducted qualitatively based on the presence or absence of the identified species.

For the informative analysis of the micropaleontological content (smaller foraminifera and ostracods), 2 samples (samples 1 and 4) were prepared following the standard method (drying, soaking, boiling and washing over a 63 $\mu \mathrm{m}$ mesh sieve - Armstrong \& Brasier, 2005).

15 samples with molluscs have been investigated, measured, and illustrated.

Facies analysis was made exclusively in the field, in order to identify depositional mechanisms and variations in sediment supply into the basin.

\section{PREVIOUSLY STUDIED PANNONIAN CALCAR- EOUS NANNOFOSSILS}

In the Central Paratethys, Jerković (1970, 1971) performed the first studies on calcareous nannofossil assemblages. He described a new genus, Noelaerhabdus, with three species: Noelaerhabdus bozinovicae, N. bekei, N. braarudi, from Pannonian sediments of Belgrade area, in Serbia \& Montenegro. Bóna (1964) and Bóna \& Gál (1985) described calcareous nannoplankton assemblages from sediments with Congeria banatica (Mecsek Mountain, Hungary), which contain: Noelaerhabdus signatories, $N$. jerkovici and $N$. tegulatus and a new genus - Bekelithella, respectively Bekelithella echinata species.

Mihajlović (1993) described a new genus of Pannonian calcareous nannoplankton, Prenoelaerhabdus, from Pannonian sediments of Vojvodina (North Serbia).

Ćorić \& Gross (2004) and Ćorić (2005) mentioned calcareous nannoplankton from early Pannonian of the Austrian Basin: Isolithus and Noelaerhabdus species.

Previous studies concerning the Pannonian calcareous nannoplankton from Romania were realized in Banat area (SW Romania) by Mărunţeanu (1995), where a Pannonian nannoplankton zonation was carried out (Mărunţeanu, 1997b). Other studies concerning the calcareous nannofossils from Romania were realised by Chira et al., 2000; Chira, 2006a, b; Chira \& Malacu, 2008; Chira et al., (2018, 2019a, b); Ćorić in Botka et al. (2019).

In the Middle Pannonian the calcareous nannofossil assemblages contain: Noelaerhabdus bozinovicae, N. bekei, N. tegulatus, N. jerkovici, Bekelithella echinata (Mărunţeanu, 1997a).

The Pannonian deposits from the western Transylvanian Basin, between Lopadea Veche and Gârbova - Gârboviţa area, contain endemic calcareous nannofossils, represented especially by two species of the genus Isolithus: Isolithus semenenko and Isolithus pavelici.

The genus Isolithus was described by Luljeva (1989) from the Eastern Paratethys. The form with three rays, Isolithus semenenko was described for the first time from the Lower Kimmerian, which corresponds to Dacian (Pliocene). These star-shaped nannofossils which present morphological similarities with the discoasters were also described from the Central Paratethys by Ćorić, 2004 and Ćorić in Botka et al., 2019.

Pannonian calcareous nannofossils of the genera Noelaerhabdus and Bekelithella were mentioned from Romania by Mărunţeanu $(1995,1997)$ and Ćorić in Botka et al. (2019).

Starting from the Noelaerhabdus evolution, two nannoplankton biozones were defined: Noelaerhabdus bozinovicae Zone (Middle Pannonian) and Noelaerhabdus bonagali Zone (Late Pannonian).

The comparison areas used in this study are located in the Aiud and Sibiu area and were studied by Chira (2006a, b) and Chira \& Malacu (2008).

Below is a short description of the calcareous nannofossil assemblages from the mentioned areas:

\section{Pannonian deposits from Lopadea Veche}

The Pannonian deposits from Lopadea Veche contain the two species of the genus Isolithus: Isolithus semenenko and Isolithus pavelici. From these, Isolithus semenenko dominates while Isolithus pavelici subordinately appears. At Lopadea Veche, Noelaerhabdus cf. bozinovicae, Noelaerhabdus sp., Braarudosphaera bigelowii and ascidian spicules were also observed. Excepting the genus Noelaerhabdus, the other species are probably reworked from Middle Miocene and even from Cretaceous (Chira, 2006a).

\section{Pannonian deposits from Gârbova - Gârboviţa area}

The analysed samples from Gârbova - Gârboviţa area contain generally larger species of Isolithus semenenko and Isolithus pavelici, compared to those of Lopadea Veche. The assemblages contain also: Coccolithus pelagicus, C. miopelagicus, Braarudosphaera bigelowii (Chira, 2006a).

\section{Pannonian deposits from Geoagiu de Sus}

The Pannonian deposits from Geoagiu de Sus contain the two species of the genus Isolithus: Isolithus semenenko and Isolithus pavelici and Noelaerhabdus cf. jerkovici.

\section{Pannonian deposits from Decea quarry}

From the western border of the Transylvanian Basin, in the Decea quarry, Isolithus semenenko and Isolithus pavelici, reticulofenestrids and ascidian spicules were observed in some samples.

\section{Pannonian deposits from Apoldu - Vurpăr}

In the southern Transylvanian Basin, near Sibiu, in Apoldu - Vurpăr area, Pannonian assemblages are present, and dominated by species of Noelaerhabdus and Isolithus, together with Coccolithus pelagicus and Helicosphaera carteri (Chira \& Malacu, 2008). 


\section{RESULTS}

\section{GUŞTERIŢA QUARRY - SIBIU}

\section{Sedimentological features}

The studied sections from Guşteriţa quarry have been noted A, B and C (Fig. 2).

The dominant lithology is represented by mudstones showing generally a very low content of silt especially made of quartz fragments representing a poor clastic input from the basin hinterland.

In the upper part, the formation makes a transition to polygenic alluvial conglomerates with intercalations of poorly consolidated sandstones.

At some levels, fragments of carbonized woods have been detected.

Rarely appear fish scales.

\section{Calcareous nannofossil assemblages}

\section{Guşterița quarry - Sibiu}

The calcareous nannofossils from the studied sections (A, $\mathrm{B}$ and $\mathrm{C}$ ) have been investigated in detail and the representative taxa were illustrated in this paper's graphic material (Fig. 2; Fig.3a-t; Fig 4 a-h).

\section{Guşteriţa - Section A.}

From the first section, 6 samples have been collected and studied concerning the calcareous nannofossils.

At the base of the first section (samples 1, 3 and 4) very frequent Pannonian calcareous nannofossils are present in different proportions: Noelaerhabdus bozinovicae (NN10 - NN11) (after Martini, 1971), N. tegulatus (= Reticulofenestra tegulata), Isolithus semenenko and I. pavelici. Species with a large distribution in the entire Miocene together with reworked taxa from Miocene, Paleogene and even Cretaceous are also present.

At some levels there are very frequent ascidian spicules (samples 4, 5 and 6). In sample 6, ascidian spicules are quite frequent together with rare calcareous nannoplankton.

In the calcareous nannoplankton assemblages, reticulofenestrids: Reticulofenestra pseudoumbilicus, R. haqii; sphenoliths: Sphenolithus moriformis, S. abies; helicospheres: Helicosphaera carteri, H. wallichii, H. walbersdorfensis; discoasters: Discoaster variabilis, D. brouwerii, D. cf. exilis, D. musicus; umbilicospheres: Umbilicosphaera jafari, U. rotula; Cycligargolithus floridanus; Calcidiscus leptoporus, C. macintyrei, C. pataecus; Coccolithus pelagicus, C. miopelagicus; Syracosphaera histrica, Rhabdosphaera pannonica, Pontosphaera multipora appear.

Rarely, Holodiscolithus macroporus, Scyphosphaera cf. lagena (NN7 - NN18) and Braarudosphaera bigelowii are also present.

From the upper part of the section, 4 samples were collected. All these samples contain species of Isolithus: I. semenenko and I. pavelici and of Noelaerhabdus: $N$. bozinovicae (NN10 - NN11) and N. tegulatus (= Reticulofenestra tegulata).

The following are also present: Reticulofenestra pseudoumbilicus, Sphenolithus moriformis, S. heteromorphus (reworked from Badenian); Helicosphaera carteri, $H$. wallichii, H. walbersdorfensis; Rhabdosphaera pannonica, Umbilicosphaera rotula, Cycligargolithus floridanus, Calcidiscus leptoporus, Coccolithus pelagicus, C. miopelagicus, Pontosphaera multipora, Discoaster druggii (reworked from the Lower Miocene).

Sometimes entire coccospheres of Coccolithus pelagicus are present.

Reworked species from Miocene, Paleogene and Cretaceous were also remarked.

Two samples were prepared for the micropaleontological content. Sample 1 contains small planktonic foraminifera reworked from the Sarmatian, and Sample 4 includes fragments of ostracods and rare Amplocypris cf. reticulata and Candona cf. lunata, which prove the Pannonian age.

\section{Guşterița - Section B.}

The samples from the second section of the quarry, contain species of Isolithus: I. semenenko and I. pavelici and of Noelaerhabdus: N. bozinovicae (NN10 - NN11) and N. tegulatus (= Reticulofenestra tegulata).

Reworked species from Miocene, Paleogene and Cretaceous were also remarked.

\section{Guşterița - Section C.}

The third section from Guşteriţa belongs to the upper part of the quarry. A level rich in molluscs was observed in the lower part of this section.

At the base of the section very frequent ascidian spicules, and Coccolithus pelagicus and rarely Isolithus were identified. The next sample contains very frequent Isolithus pavelici and I. semenenko, ascidian spicules and rarely Paleogene and Neogene taxa. The next sample in the succession contains frequent Isolithus species, larger than in the other samples, and sometimes Coccolithus pelagicus. At the top of the section Isolithus species appear rarely, sometimes Helicosphaera carteri is present, and frequent reworked species were observed.

\section{Ostracods and foraminifera}

The study of foraminifera and ostracods was based only on two samples and provides a basic overview of this additional micropaleontological content. Sample 1 contains small planktonic foraminifera reworked from the Sarmatian. Sample 4 includes rare Candona species with a poor preservation and other broken parts of ostracods (Fig. 4 i,j,k). 


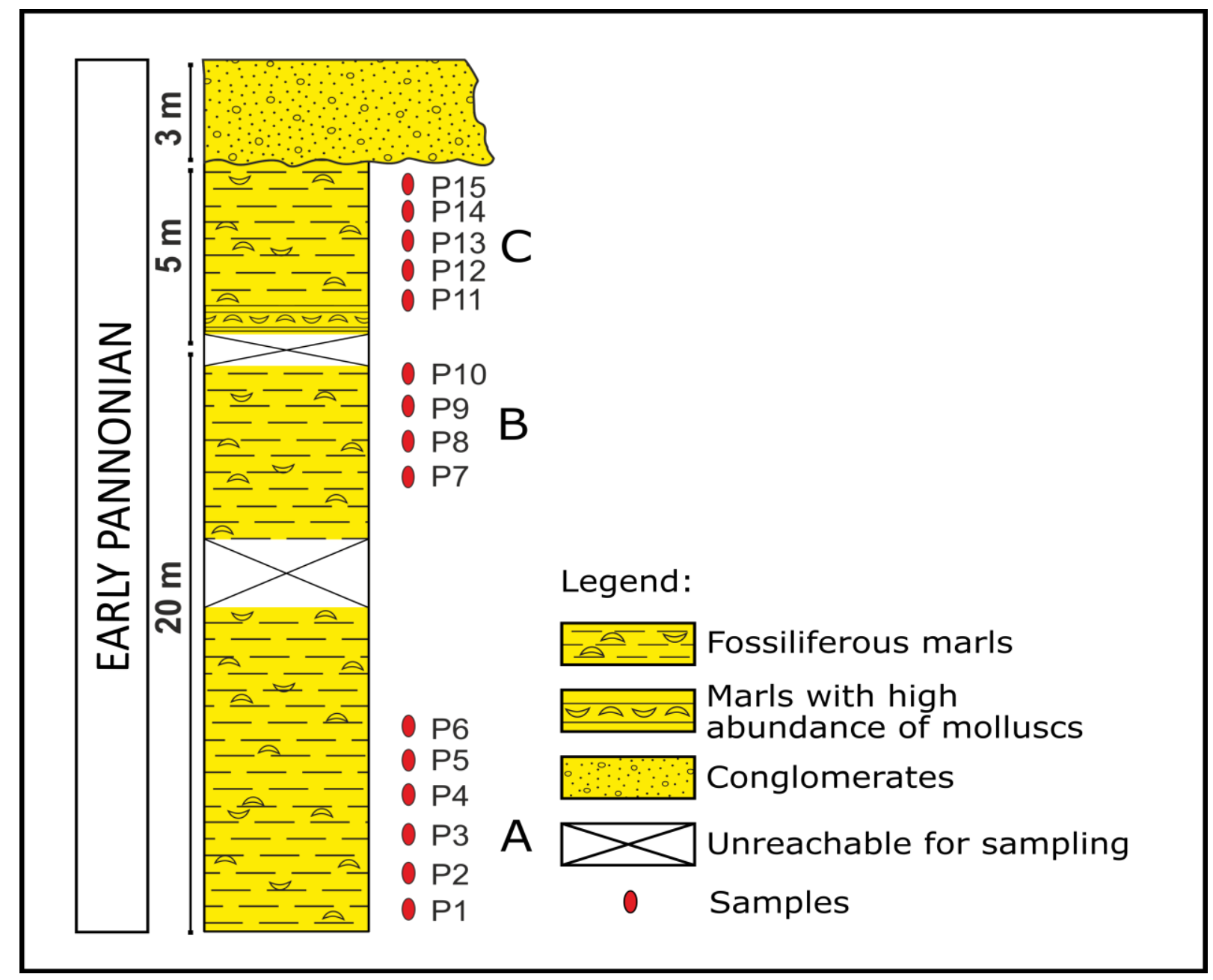

Fig. 2 Guşteriţa quarry - A, B, and C sections.

\section{Molluscs}

The molluscs samples were collected from section $\mathrm{C}$, in the right side of the upper part of the Gusterita quarry. Seven molluscs taxa have been determined. The assemblage includes four bivalve species: Congeria banatica (Dreissenidae), Lymnocardium promultistriatum, Paradacna lenzi, Paradacna syrmiense (Cardiidae), and three gastropod species: Gyraulus tenuistriatus, Gyraulus ponticus (Planorbidae) and Undulotheca halavatsi (Lymnaeidae) (Fig. 5).

The most common bivalve species is Congeria banatica, which appears as monospecific accumulations and occur with variable valves orientation. This species is frequent in the marly intervals of the quarry and has thin and fragile valves, compared to other widespread Pannonian congeries species of the Pannonian Basin.

The biostratigraphy of the Pannonian Basin deposits was made for a long time only with the help of the molluscs. Magyar et al. (1999b) separated two zones (Congeria banatica zone and "Congeria" digitifera zone) for the deep-water deposits of the basin.

The assemblage with Congeria banatica have been reported in the southern part of the Transylvanian Basin, in the early Pannonian deep water facies of the Guşteriţa marls (Lubenescu, 1981, Lubenescu, 2016). In the left part of the Guşteriţa quarry; 23 molluscs taxa have been identified and were assigned to the Congeria banatica Zone (Botka et al., 2019).

The molluscs fauna collected in the right side of the same marls (present study) confirms the presence of the Congeria banatica Zone throughout the quarry.

\section{DISCUSSIONS}

Regarding the calcareous nannofossils, according to Mărunţeanu (1997b), Prenoelaerhabdus banatensis was the first species of Noelaerhabdaceae family from the Early Pannonian. In the middle Pannonian, Noelaerhabdus bozinovicae, N. bekei, N. tegulatus, Bekelithella echinata were specific. In late Pannonian, Noelaerhabdus bonagali, Noelaerhabdus mehadicus and Bekelithella species occur. It was presumed that the Noelaerhabdus and Bekelithella species belong to NN9 (partim), NN10 and NN11 (partim). These data are from Banat, SouthWestern Romania, especially from Caransebes-Mehadia Basin.

Because Noelaerhabdus bozinovicae is present in the Transylvanian Basin at the level of Congeria banatica 


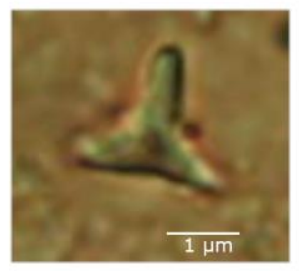

a

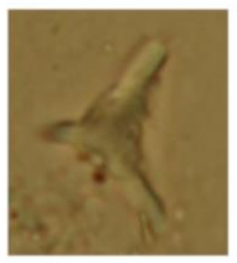

e

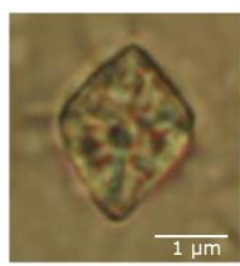

i

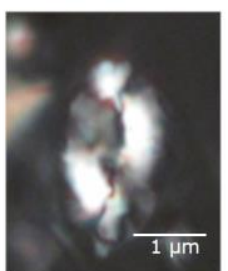

m

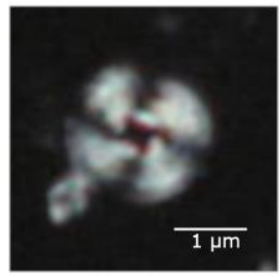

q

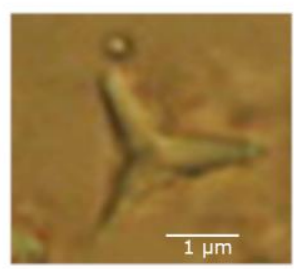

b

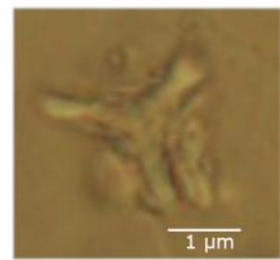

$\mathbf{f}$

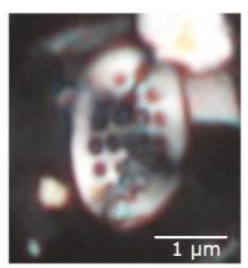

j

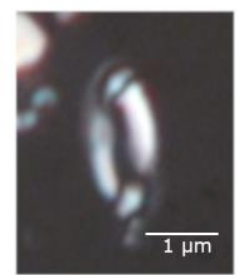

$\mathbf{n}$

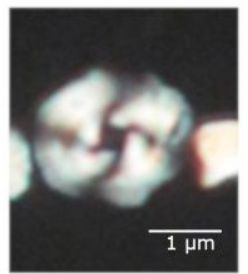

r

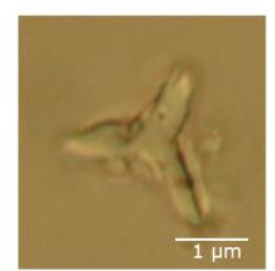

C

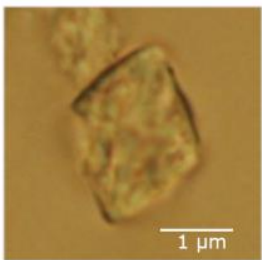

g

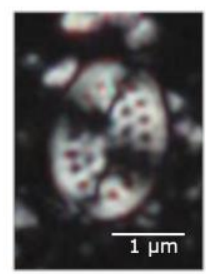

$\mathbf{k}$

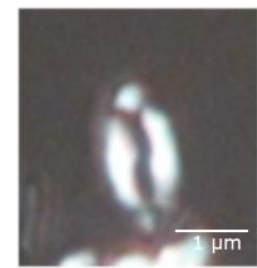

o

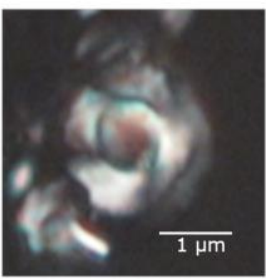

$\mathbf{S}$

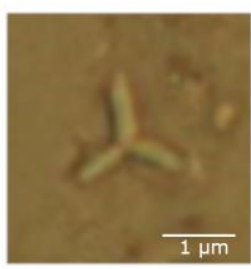

d

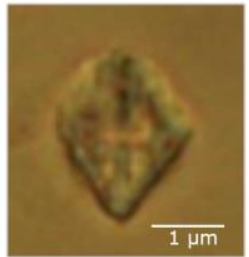

h

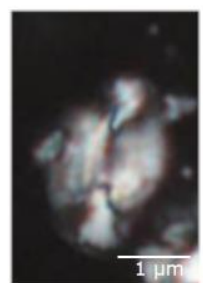

I

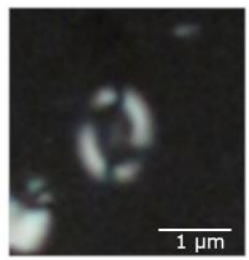

p

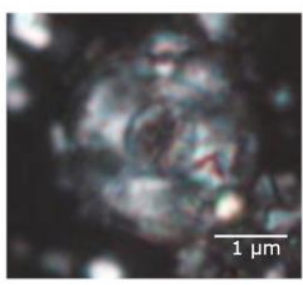

t

Fig. 3 Calcareous nannofossils from Guşteriţa quarry: a - f Isolithus semenenko Lyulieva, 1989; g - i Isolithus pavelici Ćorić \& Vrsaljko; j, k Pontosphaera multipora (Kamptner, 1948 ex Deflandre in Deflandre \& Fert, 1954) Roth, 1970; 1 Helicosphaera carteri (Wallich 1877) Kamptner, 1954; m Helicosphaera wallichii (Lohmann 1902) Okada \& McIntyre, 1977; n, o Helicosphaera walbersdorfensis Müller, 1974; p Noelaerhabdus sp.; q Ascidian spicule; r, s Cyclicargolithus floridanus (Roth \& Hay, in Hay et al., 1967) Bukry, 1971.; t Calcidiscus leptoporus (Murray \& Blackman 1898) Loeblich \& Tappan, 1978. 


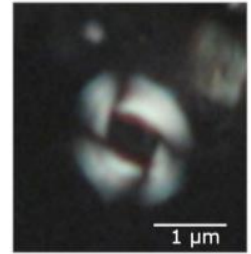

a

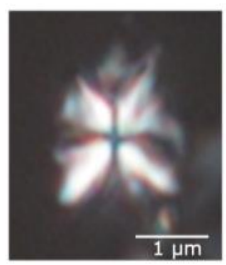

d

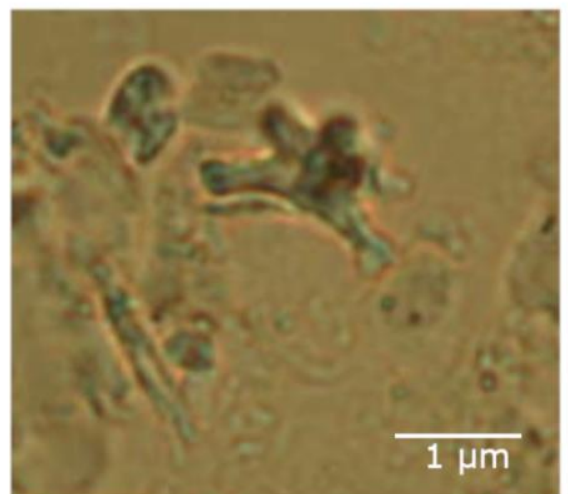

g

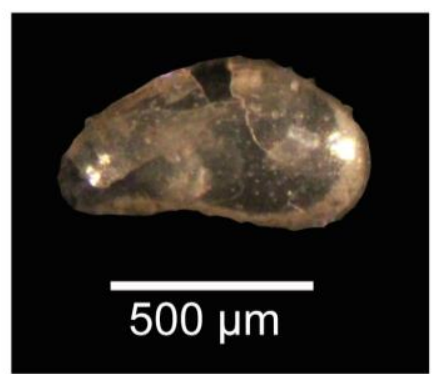

i

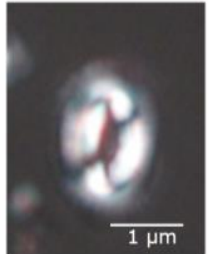

b

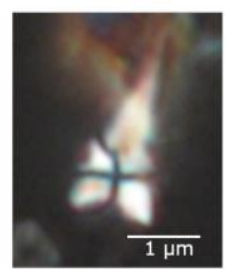

e

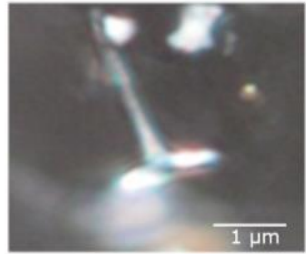

C

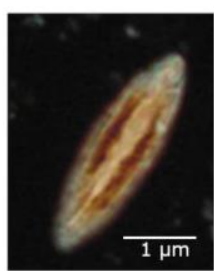

f

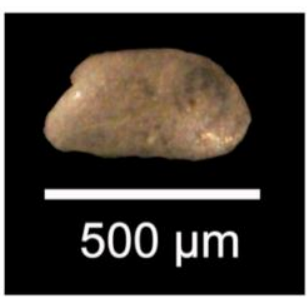

j

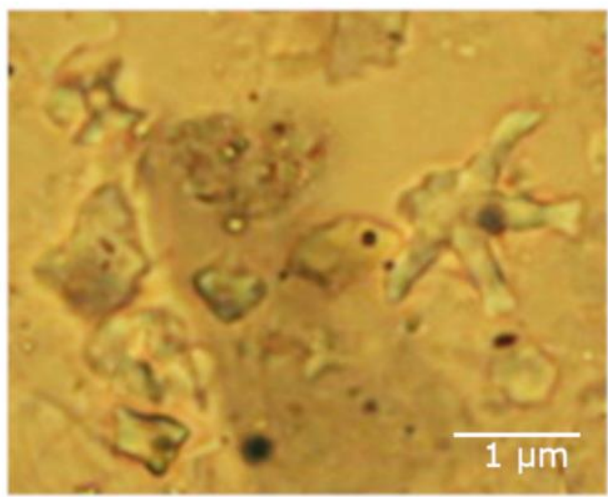

h

Fig. 4 Calcareous nannofossils from Guşteriţa quarry: a Reticulofenestra pseudoumbilicus (Gartner, 1967) Gartner, 1969; b Coccolithus pelagicus (Wallich 1877) Schiller, 1930; c Calcidiscus leptoporus (Murray \& Blackman 1898) Loeblich \& Tappan, 1978; d Sphenolithus moriformis (Brönnimann \& Stradner, 1960) Bramlette \& Wilcoxon, 1967; e Sphenolithus heteromorphus Deflandre 1953; f. Rhabdosphaera pannonica Baldi-Beke, 1960; g Calciosolenia murrayi Gran, 1912 and Discoaster variabilis Martini and Bramlette, 1963; h Pannonian calcareous nannofossils assemblages with Isolithus pavelici and I. semenenko; Discoaster cf. variabilis.; i Candona sp. Baird, 1845 right valve; j Candona sp. Baird, 1845 right valve; k fragment of Candona sp. 


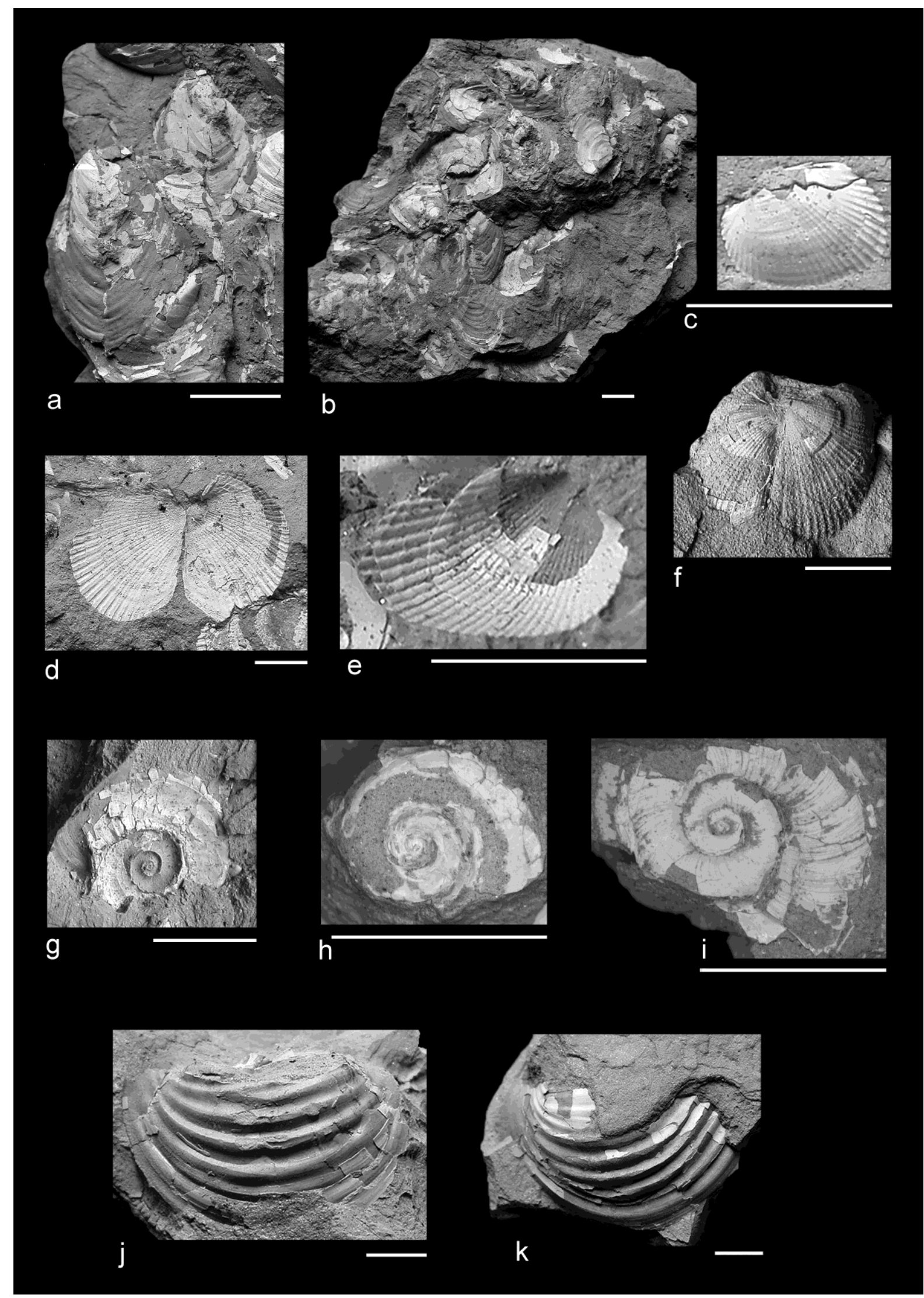

Fig. 5 The molluscs species of the Guşteriţa quarry. Scale bar $1 \mathrm{~cm}$. a Congeria banatica R. Hoernes, 1875; b Congeria banatica - monospecific assemblage; c Lymnocardium cf. promultistriatum Jekelius, 1944; d-e Paradacna lenzi (R. Hoernes, 1874); f Paradacna syrmiense (R. Hoernes, 1874); g-h Gyraulus tenuistriatus (Gorjanović-Kramberger, 1899); i Gyraulus ponticus (Lörenthey, 1893); j-k Undulotheca halavatsi Gorjanović-Kramberger, 1901. 
(early Pannonian), it is probable that in the Transylvanian Basin it was present earlier than the middle Pannonian, as previously thought.

Corić in Botka et al. (2019) attributed the sediments from Gușterița quarry to the Noelaerhabdus bozinovicae zone, based on the presence of Noelaerhabdus bozinovicae, $N$. jerkovici and the absence of $N$. bonagali.

Galović \& Young (2012) considered the presence of Noelaerhabdus bozinovicae from Badenian /Sarmatian until Pannonian, in the North Croatian Basin, but mentioned a lot of species of Noelaerhabdus as synonyms.

The evolution of the Pannonic Basin influenced the evolution of the molluscs fauna.

The latest scientific research places the moment of the isolation of the Pannonian Lake about $11.6 \mathrm{Ma}$ ago (Harzhauser et al., 2007; Rundić et al., 2011; Neubauer et al., 2016).

During the evolution in the intra-Carpathian area, it occupied variable surfaces with different depths depending on the sedimentation rates (Magyar et al., 1999a); its development was also influenced by the evolution of the Carpathian orogen (Krézsek \& Filipescu, 2005; Krézsek et al., 2010). The brackish waters, which have gradually become rich in freshwater, have favored the development of endemic species of bivalves and gastropods (Müller et al., 1999; Magyar, 2004; Neubauer et al., 2016). The Transylvanian Basin was flooded by the waters of the Pannonian Lake about 11.5 Ma ago, having a particular evolution of a semi-isolated basin (Krézsek et al., 2010). This has generated low species diversity with many endemic species (Lubenescu, 1981; Neubauer et al., 2016). Despite these restrictive conditions for Pannonian faunas, there has been a favorable period to the development of the $C$. banatica assemblage in deep marine environments. This assemblage was also reported from the western part of the Transylvanian Basin (Lubenescu \& Lubenescu, 1977) and in some deep-water facies occurrences from the Pannonian Basin, being considered early Pannnonian in age (Gorjanović - Kramberger, 1899, 1901, 1923; Sremac, 1981; Magyar et al., 1999a, 1999b; Ganić et al., 2010; Rundić et al., 2011).

The presence of reworked planktonic foraminifera from Sarmatian is consistent with the findings of Botka et al. (2019) from the same deposits. The low diversity and very poor preservation of the identified ostracods are in contrast to the Pannonian ostracoda assemblages identified by Filipescu et al. (2011) and Botka et al. (2019) which were described as abundant and more diverse. This low presence and poor preservation may be due to particularly stressful conditions for this group in the interval from where sample 4 was collected. We claim that the best data based on ostracods for the Guşteriţa section are those provided by Botka et al. (2019) since their study was made at a very high-resolution on this group; the authors attributed the dominance of the thin-shelled Candoninae to a sublitoral to profundal depositional palaeo- environment, below the storm-wave base (as indicated by their thin-shells).

Sedimentologically, the transition between the mudstones showing generally a very low content of silt especially made of quartz fragments to the polygenic alluvial conglomerates with intercalations of poorly consolidated sandstones suggests a regional uplift of the Transylvanian Basin during Pannonian.

\section{CONCLUSIONS}

Three sections from Guşteriţa quarry have been investigated especially concerning the calcareous nannofossil assemblages, with remarks about molluscs, ostracods and facies analysis.

The nannofossil content of these sections was compared with seven other Pannonian sections respectively located from the western and southern border of the Transylvanian Basin.

In the sections of Guşteriţa quarry, the presence of the Congeria banatica zone indicate a deep water facies in the early Pannonian age.

In conclusion, based on calcareous nannoplankton, Guşteriţa Formation can be considered Upper Miocene (early Pannonian) in age (Noelaerhabdus bozinovicae Biozone). The formation was sedimented into a low energy basin with very reduced clastic input.

\section{ACKNOWLEDGMENTS}

We thank our students who helped us in the field trips from 2017 to 2019. We also thank the reviewers for the suggestions and comments on the manuscript.

\section{REFERENCES}

Ackner, M., 1852. Fundgrube fossiler Ueberreste zu Hammersdorf bei Hermannstadt. Verhandlungen und Mittheilungen des siebenbürgischen Vereins für Naturwissenschaften zu Hermannstadt, III/1: 6-11.

Armstrong, H. A. \& Brasier, M. D., 2005. Microfossils (Second Edition). Oxford: Blackwell Publishing, 304 pp.

Baranyi, V., Bakrač, K., Krizmanić, K., Botka, D., Šujan, M., Braucher, R. \& Magyar, I., 2019. Palynology of a New Lower Pannonian (Upper Miocene) Reference Section from the Transylvanian Basin (Romania). In: Horvat, M. Matoš, B \& Wacha, L (eds.) 6th Croatian Geological Congress with international participation. Abstract Book, Zagreb: Croatian Geological Survey, pp. 21-22.

Baranyi, V., Bakrač, K., Krizmanić, K., Botka, D., Tóth, E. \& Magyar, I., 2021. Paleoenviromental changes and vegetation of the Transylvanian Basin in the early stages of Lake Pannon (late Miocene, Tortonian). Review of Palaeobotany and Palynology, 284: 1-16. https://doi.org/10.1016/j.revpalbo.2020.104340 
Bielz, A., 1894. Pontische Ablagerungen in Siebenbürgen. Verhandlungen und Mitteilungen des Siebenbürgischen Vereins für Naturwissenschaften zu Hermannstadt, 43: 94-96.

Bóna, J., 1964. Coccolithophoriden - Untersuchungen in der neogenen Schichtenfolge des Mecsek Gebirges. Földtani Közlöny, 94: $121-131$.

Bóna, J. \& Gál, M., 1985. Kalkiges Nannoplankton im Pannonien Ungarns. In: Papp, A., Jambor, A. \& Steininger F.F.: Chronostratigraphie und Neostratotypen. Miozän der Zentralen Paratethys, Pannonien - 7 (M6), pp. 482 - 515.

Botka, D., Magyar, I., Sujan, M. \& Braucher. R., 2018. The Early Pannonian (Late Miocene) stratigraphic research of the Transylvanian Basin (Romania): New Biostratigraphic and authigenic ${ }^{10} \mathrm{Be} /{ }^{9} \mathrm{Be}$ Isotopic Data. In: Horvath, M. \& Wacha, L. (eds) $7^{\text {th }}$ International Workshop, Neogene of Central and South-Eastern Europe, Abstracts Book, pp. 15-16.

Botka, D., Magyar, I., Csoma, V., Toth, E., Sujan, M., Ruszkiczay-Rüdiger Z., Chyba, A., Braucher, R., Sant, K., Ćorić, S., Baranyi, V., Bakrač, K., Krizmanić K., Bartha, I.R., Szabó M. \& Silye, L., 2019. Integrated stratigraphy of the Guşteriţa clay pit: a key section for the early Pannonian (late Miocene) of the Transylvanian Basin (Romania). Austrian Journal of Earth Sciences Vienna, 112(2): 221-247, DOI:10.17738/ajes.2019.0013.

Bown, P.R. \& Young, J.R., 1998. Techniques. In: Bown, P.R. (ed.), Calcareous Nannofossil Biostratigraphy (British Micropalaeontological Society Publications Series), Chapman and Kluwer Academic, London, pp. 16-28.

Chira, C., Filipescu, S. \& Codrea, V., 2000. Palaeoclimatic evolution in the Miocene from the Transylvanian Depression reflected in the fossil record. In: Hart, M.B. (ed.), Climates: Past and Present. Geological Society, London, Special Publications, 181: 55-64. https://doi.org/10.1144/GSL.SP.2000.181.01.06

Chira, C., 2006a. Pannonian calcareous nannofossils from southern Transylvania: Lopadea - Gârbova area. Anuarul Institutului Geologic al României, 74(1): 34 35.

Chira, C.M., 2006b. Upper Miocene calcareous nannofossils from Transylvania, Romania. Abstracts of the $11^{\text {th }}$ International Nannoplankton Association Conference, Lincoln, Nebraska, pp. 27-29.

Chira, C.M. \& Malacu, A., 2008. Biodiversity and palaeoecology of the Miocene calcareous nannoplankton from Sibiu area (Transylvania, Romania). Acta Palaeontologica Romaniae, 6: 17-28.

Chira, C.M., Haitonic R., Aroldi C., Şerban S.-N. \& Suciu T.-I. \& Bunu, E., 2018. Pannonian calcareous nannofossils from Guşteriţa quarry (southern Transylvanian Basin, Romania). In: Filipescu, S. \& BindiuHaitonic, R. (eds.) Sesiunea ştiintifică anuală "Ion Popescu Voiteşti” Departamentul de Geologie al Uni- versităţii Babeş-Bolyai, Presa Universitară Clujeană, pp. 7-8.

Chira, C.M., Aroldi, C., Serban, S.N. \& Suciu T.I., 2019a. Pannonian calcareous nanofossils from the Transylvanian Basin, Romania (Central Paratethys). In: Studencka, B. (ed.) 8th International Workshop on Neogene of Central and South-Eastern Europe. Abstract Volume and Field Trip Guidebook, Centrum Poligrafii Sp z.o.o., pp. 32-34.

Chira, C.M., Aroldi, C., Vieru, S.C., Mateiu, A., Serban, S.N. \& Suciu T.I., 2019b. Guşteriţa quarry (Sibiu): the Pannonian calcareous nannofossils. In: Har, N. (ed). Sesiunea ştiintifică anuală "Ion Popescu Voiteşti” Departamentul de Geologie al Universităţii Babeş-Bolyai, Presa Universitară Clujeană, pp. 26-27.

Ćorić, S., 2004. Occurences of endemical Pannonian calcareous nannoplankton genus Isolithus Luljeva, 1989 in the Central Paratehys. Scripta Facultatis Scientiarum Naturalium Universitis Masarykianae Brunensis, Geology, 31-32: 19-22.

Ćorić, S. \& Gross, M., 2004. Kalkiges Nannoplankton aus dem Unter-Pannonium des Oststeirischen Beckens (Österreich). Joannea Geologie und Paläontologie, 5: 9-18.

Ćorić, S., 2005. Endemic Sarmatian and Pannonian calcareous nannoplankton from the Central Paratethys. In: Harzhauser, M. \& Zuschin, M. (eds.) 12th RCMNS Congress, Abstracts, pp. 53-54.

Dessila Codarcea, M., Dimitrescu, R. \& Stancu. I., 1968. Geological map of Romania, 1:200.000, sheet 27 (Sibiu). Institute of Geology, Bucharest.

Filipescu, S., Wanek, F., Miclea, A., De Leeuw, A. \& Vasiliev, I., 2011. Micropaleontological response to the changing paleoenvironment across the SarmatianPannonian boundary in the Transylvanian Basin (Miocene, Oarba de Mures section, Romania). Geologica Carpathica, 62(1): 91-102. DOI:10.2478/v10096-0110008-9

Galović, I. \& Young, J.R., 2012. Revised taxonomy and stratigraphy of Middle Miocene calcareous nannofossils of the Paratethys. Micropaleontology, 58(4): 305334.

Ganić, M., Rundić, L., Knežević, S. \& Cvetkov, V., 2010. The Upper Miocene Lake Pannon marl from the Filijala Open Pit (Beočin, northern Serbia): new geological and paleomagnetic data. Annales Géologiques de la Péninsule Balkanique, 71: 95-108. DOI:10.2298/GABP1071095G

Gorjanović-Kramberger K., 1899. Die Fauna der unterpontischen Bildungen um Londjica in Slavonien. Jahrbuch der kaiserlicht-königlichen geologischen Reichsanstalt, 49: 125-134.

Gorjanović-Kramberger K., 1901. Über die Gattung Valenciennesia und einige unterpontische limnaeen, ein beitrag zur entwickelungsgeschichte der gattung Valenciennesia und ihr verhältnis zur gattung Limnaea. Beiträge zur Paläontologie und Geologie Österreich-Ungarns und des Orients, 13(3): 121-140. 
Gorjanović-Kramberger K., 1923. Über die Bedeutung der Valenciennesiiden in stratigraphischer und genetischer Hinsicht. Paläontologische Zeitschrift, 5(3): 339-344.

Harzhauser, M., Latal C. \& Piller W., E., 2007. The stable isotope archive of Lake Pannon as a mirror of Late Miocene climate change. Palaeogeography, Palaeoclimatology, Palaeoecology, 249: 335-350. DOI:10.1016/j.palaeo.2007.02.006

Hoernes R., 1875. Valenciennesia-Schichten aus dem Banat. Jahrbuch der kaiserlicht-königlichen geologischen Reichsanstalt, 25: 73-77.

Jekelius E., 1944. Sarmat und Pont von Soceni (Banat). Memoriile Institutului Geologic al României, 5: 7167.

Jerković, L., 1970. Noelaerhabdus nov. gen. type d'une nouvelle famille de Coccolithophoridés fossils: Noelaerhabdaceae du Miocène supérieur de Yougoslavie. Comptes rendus hebdomadaires des séances de l'Académie des Sciences, d, 270 (1): 468-470.

Jerković, L., 1971. Noelaerhabdus bekei nov. sp. des Coccolithophoridés de Belgrade. Bull. Sci. C.R. Acad. Sci. Paris, 16a (7-8): 206-208.

Krézsek, C. \& Filipescu, S., 2005. Middle to late Miocene sequence stratigraphy of the Transylvanian Basin (Romania). Tectonophysics, 410: 437-463. DOI:10.1016/j.tecto.2005.02.018

Krézsek, C. \& Bally, A. W. 2006. The Transylvanian Basin (Romania) and its relation to the Carpathian fold and thrust belt: Insights in gravitational salt tectonics, Marine and Petroleum Geology, 23(4): 405442, doi:10.1016/j.marpetgeo.2006.03.003

Krézsek, C., Filipescu, S., Silye, L., Matenco, L. \& Doust, H., 2010. Miocene facies associations and sedimentary evolution of the southern Transylvanian Basin (Romania): Implications for hydrocarbon exploration. Marine and Petroleum Geology, 27(1): 191-214, doi:10.1016/j.marpetgeo.2009.07.009.

Lörenthey E., 1893. Beiträge zur Kenntniss der unterpontischen Bildungen der Szilágyer Comitates und Siebenbürgens. Revue über den inhalt des Értesitő. Sitzungsberichte der medicinischnaturwissenschaftlichen section des siebenbürgischen museumvereins. I. Naturwissenschaftliche abtheilung. 15(3): 289-322.

Lyulieva, S. A., 1989. New Miocene and Pliocene calcareous nannofossils of the Ukraine. Dopovidi Akad. Nauk Ukrainskoi RSR Ser. B. - Geol. Khim. ta Bioi. Nauki,.1: 10-14.

Lubenescu, V. \& Lubenescu, D., 1977. Biostratigraphic Observations on the Lopadea Veche Pannonian (Transylvania Depression). Dări de Seamă ale Şedinţelor, Institutul de Geologie şi Geofizică, 63(4): 57-64. (in Romanian, with English abstract)

Lubenescu, V., 1981. Studiul biostratigrafic al Neogenului superior din sud-vestul Transilvaniei. [Biostratigraphic study of the Upper Neogene in the south-west of Transylvania]. Anuarul Institutului de
Geologie şi Geofizică Bucureşti, 58: 123-202. (in Romanian and French, with English abstract).

Lubenescu, V., 2016. Biostratigraphic correlations between the Dacian and Pannonian basins from Romania. Geo-Eco-Marina, 22: 161-179.

Magyar, I., 2004. What lessons can we learn from the hundred-year history of the Lake Pannon mollusc biostratigraphy in Hungary?. Földtani Közlöny, 134(3): 369-390.

Magyar, I., Geary, D.H. \& Müller, P., 1999a. Paleogeographic evolution of the Late Miocene Lake Pannon in Central Europe. Palaeogeography, Palaeclimatology, Paleoecology, 147: 151-167. https://doi.org/10.1016/S0031-0182(98)00155-2

Magyar, I., Geary, D.H., Sütő-Szentai, M., Lantos, M. \& Müller, P., 1999b. Integrated biostratigraphic, magnetostratigraphic and chronostratigraphic correlations of the Late Miocene Lake Pannon deposits. Acta Geologica Hungarica, 42: 5-31.

Martini, E., 1971. Standard Tertiary and Quaternary Calcareous Nannoplankton Zonation. In: Farinacci, A. (ed.) Proceedings of the II Planktonic Conference, Roma, 1970, Ed. Tecnoscienza, pp. 739-785.

Mărunţeanu, M., 1995. Noelaerhabdus bonagali n. sp. (Calcareous Nannoplankton) in the Upper Malvensian - Romanian Banat. Romanian Journal of Paleontology, 76: 99- 100.

Mărunţeanu, M., 1997a. Evolution line of the endemic genus Noelaerhabdus (Pannonian, Pannonian Basin). Acta Palaeontologica Romaniae, 1: 96-100.

Mărunţeanu, M., 1997b. Pannonian nannoplankton zonation. Proceedings of the International Symposium "Geology in the Danube gorges", Beograd, pp. 263265.

Mihajlović, D., 1993. Praenoelaerhabdus, a new endemic genus of calcareous nannoplankton of the Pannonian Basin. Geologica Carpathica, 44(1): 59-62.

Müller, P., Geary, D.H. \& Magyar, I., 1999. The endemic molluscs of the Late Miocene Lake Pannon: their origin, evolution, and family-level taxonomy. Lethaia, 32: $\quad 47-60 . \quad$ https://dx.doi.org/10.1111/j.15023931.1999.tb00580.x

Neubauer, T. A., Harzhauser, M., Mandic, O., Kroh, A. \& Georgopoulou, E., 2016. Evolution, turnovers and spatial variation of the gastropod fauna of the late Miocene biodiversity hotspot Lake Pannon. Palaeogeography, Palaeoclimatology, Palaeoecology, 442: 84-95. https://doi.org/10.1016/j.palaeo.2015.11.016

Rundić, L., Ganić, M., Knežević, S. \& Soliman A., 2011. Upper Miocene Pannonian sediments from Belgrade (Serbia): new evidence and paleoenvironmental considerations. Geologica Carpathica, 62(3): 267-278. DOI:10.2478/v10096-011-0021-z

Sremac, J., 1981. Some New and Less Known Species of Molluscs of the Croatica-Beds and the Banatica-Beds in Northern Croatia. Geološki vjesnik, 33: 107-121. 